\title{
Summary of the fire protection foundation report - fire safety challenges of tall wood buildings
}

\author{
David Barber ${ }^{1 *}$ and Robert Gerard ${ }^{2}$
}

\begin{abstract}
Buildings constructed from engineered timber are becoming more prevalent globally as building designers, owners and architects realize the sustainability opportunities with timber construction and the overall aesthetic of a completed timber building. As timber buildings are planned to be taller than many model codes permit, the National Fire Protection Association (NFPA) Fire Protection Foundation commissioned research entitled "Fire Safety Challenges of Tall Wood Buildings", with the aim of understanding where the current gaps in knowledge are and how the research agenda should be prioritized.

With new engineered timber products such as cross-laminated timber becoming more prevalent, this study evaluated the current knowledge of tall timber construction to identify gaps in knowledge, and where if fulfilled, will provide a better understanding of the potential fire safety performance of tall timber buildings.

The study identified a number of knowledge gaps, of which most were related directly to the new technology of engineered timber products that have resulted from the use of CLT. These included system-level fire testing, use of composite assemblies, CLT char fall-off and construction fire safety. The study concluded that the priority for future research should target three areas of research, being the contribution of exposed timber to room fires; connections between timber components and timber composite assemblies; and penetrations for building services.
\end{abstract}

Keywords: Timber fire safety; Tall timber buildings; Building sustainability; Cross Laminated Timber; Research priorities

\section{Introduction}

Timber is becoming an increasingly a more desirable construction material as international architects and designers understand that timber has significant potential benefits in sustainability and construction. Traditional schemes for timber buildings as low-rise (two-stories or less) and mid-rise (three- to five-stories) are now being extended with schemes for new high-rise buildings, also referred to as tall, timber buildings (six-stories or greater).

While these buildings present ambitious designs for the future vision of tall timber structures, designers are currently limited by prescriptive code legislation. These codes restrict the potential for tall timber buildings, as height and area limitations prevent use, based on the issues of structural and fire safety. As knowledge and understanding of fire and timber buildings develops,

\footnotetext{
* Correspondence: david.barber@arup.com

${ }^{1}$ Arup, 1120 Connecticut Avenue, Washington DC, NW 20036, USA

Full list of author information is available at the end of the article
}

the potential for change in code becomes increasingly possible.

This paper provides a summary of the National Fire Protection Association (NFPA) Fire Protection Foundation "Fire Safety Challenges of Tall Wood Buildings".

\section{Timber building fundamentals}

The following section introduces timber fundamentals discussed within this study. Additional information can be found in the full paper (Barber, Gerard, \& Wolski, 2013).

Timber products, technologies, and methods of construction have evolved over time. The two most popular forms of timber framing can be categorized as:

- Light timber framing; and

- Heavy timber framing.

Light timber frame and heavy timber frame buildings have many fundamental differences, and are designed 
and constructed for different types of buildings depending on size, function, and height. However, the primary difference between light and heavy timber construction is the section size of the timber members used in construction. This has a significant impact on the fire performance and method of fire protection.

Light timber frame construction are typically encapsulated within non-combustible gypsum plasterboard to offer sound insulation, surface finishes and protection from fire. Given the section size of typical 2" $\times 4$ " [50 mm $\times 100 \mathrm{~mm}$ ] and $2 " \times 6 "$ [50 $\mathrm{mm} \times 150 \mathrm{~mm}$ ] stud framing members, the inherent fire resistance of the studs alone is effectively negligible, as the members are small. Hence, unprotected, or exposed, light timber frames provide little structural fire resistance. Fire resistance is achieved by providing protection to the light timber assembly to delay the onset of heating and combustion. Light timber framing is not discussed further within this paper as it is a construction method primarily for low-rise buildings.

Heavy timber frame construction, also called heavy frame, or heavy timber construction, is characterized by beams and columns with timber section sizes that are greater than $6 " \times 6 "[150 \mathrm{~mm} \times 150 \mathrm{~mm}]$. Engineered timber products offer greater strength and design flexibility and have become increasingly popular as building elements in tall timber construction. Generally, engineered timber/ wood consists of derivative timber products that are manufactured to increase the strength and stiffness of the engineered timber element. This includes, glulam, Laminated veneer lumber (LVL) and Cross-Laminated Timber (CLT).

\section{Timber fire fundamentals}

Research and testing have shown that the fire performance of exposed timber is generally well understood, and importantly, predictable (AWC 2003).

When timber is exposed to fire, the outer layer burns and turns to char. This occurs at a temperature of approximately $572{ }^{\circ} \mathrm{F}\left[300{ }^{\circ} \mathrm{C}\right]$ (Forintek, 2002). This creates a protective charring layer that acts as insulation and delays the onset of heating for the unheated, or cold, layer below (White 2004). This process of charring allows timber elements to achieve a level of inherent fire resistance (White 2002).

The char layer, heated zone and cold timber are shown in Fig. 1.

The section of timber in the heated zone beyond the char layer is known as the pyrolysis zone, and corresponds to temperatures between approximately $392{ }^{\circ} \mathrm{F}$ $\left[200{ }^{\circ} \mathrm{C}\right]$ and $572{ }^{\circ} \mathrm{F}\left[300{ }^{\circ} \mathrm{C}\right.$ ] (AWC 2003). Within this zone, timber is assumed to undergo thermal decomposition and pyrolysis.

The char layer, pyrolysis zone and cold/unheated timber are shown graphically in Fig. 2.

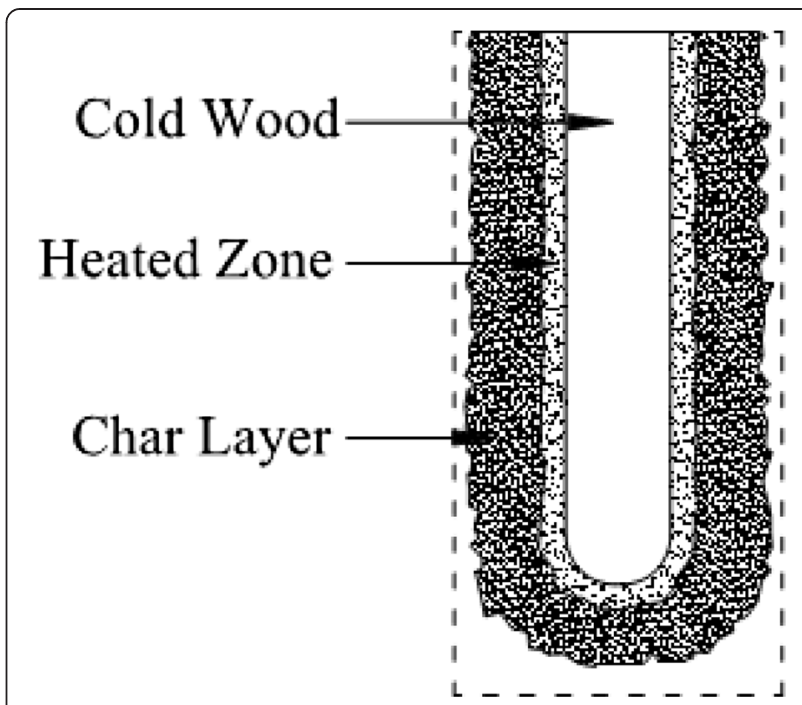

Fig. 1 Charring of a timber/wood member with exposure on three sides (AITC, 2012)

The char layer continues to grow with exposure to fire, creating even more insulation, slowing down the burning rate and reducing the unheated cross section of the member (AITC, 2012). This behavior continues until the end of heating, or the section has completely combusted.

Testing of this charring process has shown that timber demonstrates a constant, predictable charring rate (Buchanan 2001). The charring rate, section size and the required fire duration can be used to calculate the fire resistance time for a timber element (White 2002).

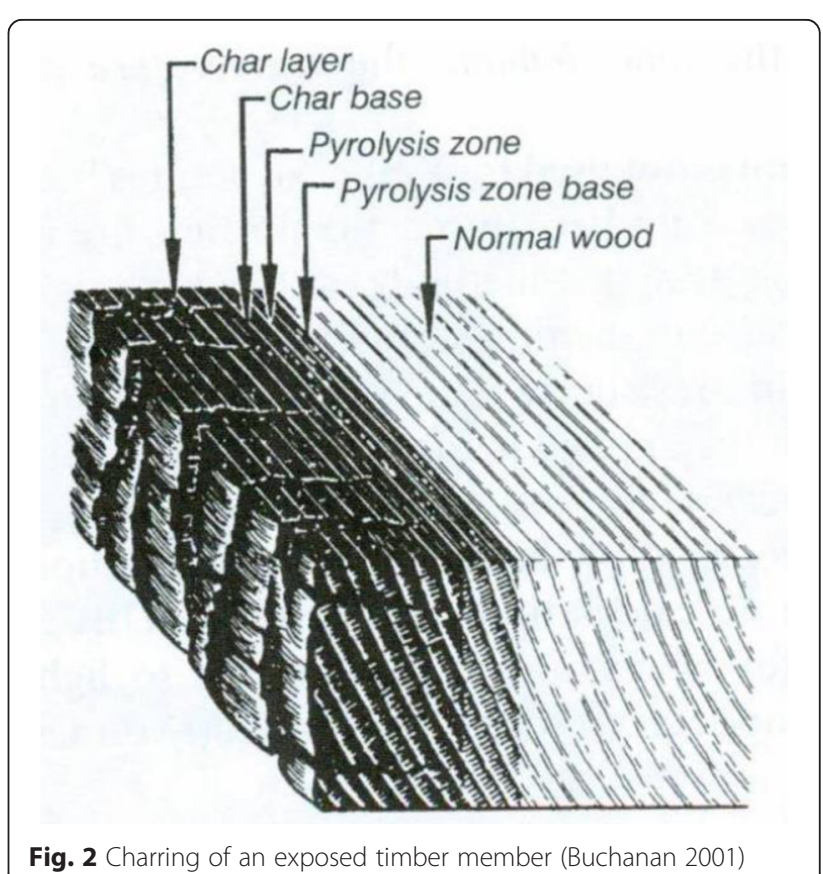


This allows for a structural fire assessment to determine if the post-fire section size is able to maintain stability at the end of fire exposure (Bregulla \& Enjily, 2004).

A post-fire, reduced or residual, section size for a timber element with four-sided exposure is shown in Fig. 3. The char layer depth for post-fire timber sections can be calculated by multiplying the charring rate by the fire exposure time to determine the reduced section properties (Frangi et al. 2008b).

The fire resistance calculation is particularly applicable to heavy timber frame members compared to light timber frame members. The larger section sizes result in significantly greater inherent fire resistance. This fire resistance can be incorporated as part of the building structural fire strategy.

\section{Fire risk during construction}

A significant advantage of heavy timber frames compared to light timber frames is the lower risk of complete burnout due to fire during construction. Heavy timber members do not rely on additional protection measures and are inherently designed to resist fire. Once exposed to fire, the charring layer provides protection for the solid, unheated timber below.

An additional benefit is the ease of repair following a fire. The charred members can be quickly visually assessed and then evaluated for residual capacity (Ross, 2005). Where deemed appropriate, the damaged timber can be cut away and replaced, or strengthened with solid timber or composite materials to provide the required structural capacity (Babrauskas, 2004) (King, 2007).

Unprotected light timber frame structures, on the other hand, can present significant fire risks, not just to the

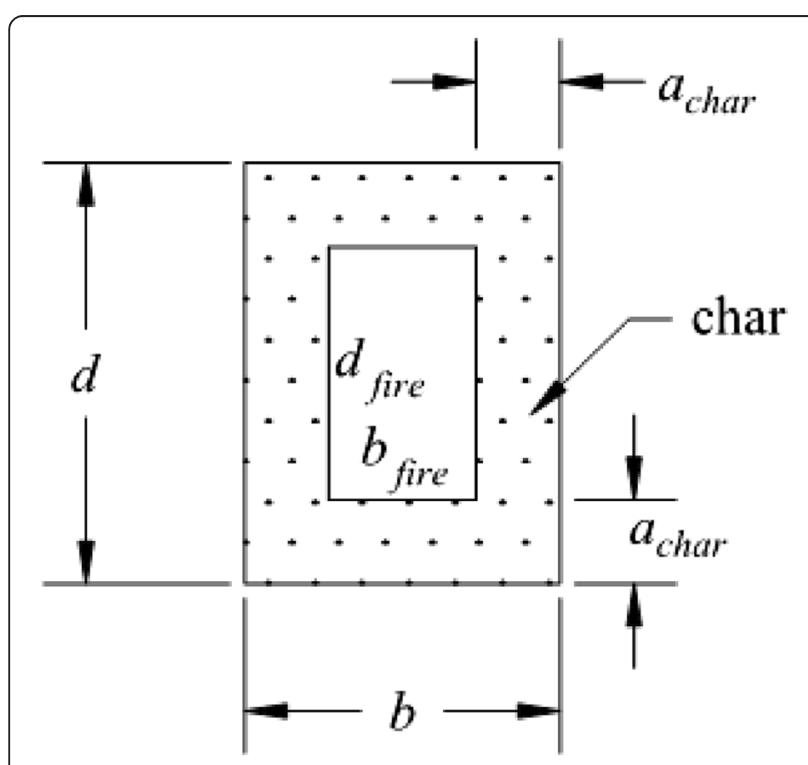

Fig. 3 Reduced dimensions of four-sided fire exposure (AITC, 2012) building site, but also adjacent buildings. This is especially true during the construction phase, prior to the completion of the fire resistive assembly with the installation of gypsum board protection. This makes light timber buildings under construction particularly vulnerable to arson (TimberFrameFires, 2011). A lack of fire protection has the potential to result in complete burnout of a timber site. This can result in large fires that can potentially threaten adjacent buildings due to severe heat exposure.

\section{Literature review}

\section{Heavy timber frame assemblies}

Whereas fire testing of light timber frame assemblies focuses on gypsum board protection for floor and wall assemblies, fire testing for heavy timber assemblies has been performed on a wider spectrum of products. Fire behavior of engineered timber is similar to that of wood sections. However, the larger section size provides a greater area, allowing the charring behavior to provide inherent fire resistance.

Multiple references provide a summary of fire test data for engineered timber products exposed to fire. Hopkin provides a comprehensive literature review of fire testing in heavy timber assemblies (Hopkin, 2011). The American Wood Council (AWC) presents design calculation methods of fire resistance of heavy timber sections compared to experimental test results (AWC 2003). Generally, results compare favorably with design equations.

The behavior for laminated veneer lumber (LVL) products is discussed in several papers. Tsai performed a series of fire tests to determine the charring rate for different sections of LVL (Tsai, 2010). Results indicated charring rates for LVL compared favorably to rates for solid wood. Harris and Lane performed fire testing with LVL sections to establish charring rates and fire performance (Harris, 2004) (Lane, 2001). Testing was also performed for structural composite lumber (SCL), which consists of laminated veneer lumber (LVL), parallel strand lumber (PSL) and laminated strand lumber (LSL) (White 2006).

Fire test results for glulam sections are documented within a number of research papers and guides. The most comprehensive work was undertaken by Lie (Lie, 1977). Further work on establishing methods of evaluating charring rate and strength was carried out by Schaffer (1986). Tests to establish the charring rates for glulam sections were also performed (Buchanan \& Moss 1999). Results for charring rates in glulam compared favorably to solid wood sections.

Primary findings from the above documents demonstrate that fire performance and charring rates of glulam, LVL and SCL are similar to that of large, solid wood sections. The engineered materials char at a constant rate when exposed to the standard fire and form the insulating char layer that protects the unheated timber below. 
Once the charring rate and section size are determined, the fire resistance time for exposed timber members can then be calculated (AITC, 2012).

The fire resistance time for wood elements can be increased by providing gypsum board protection at exposed surfaces. Fire testing with LVL beams has shown that $30 \mathrm{~min}$ fire resistance can be added for a single layer of $16 \mathrm{~mm}$ gypsum board. Application of a double layer of gypsum board indicated at least a $60 \mathrm{~min}$ increase in fire resistance time (White 2009).

With the recent trend of CLT construction, there has been considerable research in fire testing of CLT panel assemblies. CLT is shown to char at a constant rate with exposure to the standard fire. The charring rate can be used to calculate the fire resistance of the section based on the depth of the panel.

Fire testing of CLT floor beams in bending was performed to develop an advanced thermo-mechanical model that can be used to predict CLT performance in fire (Schmid, Konig, \& Kohler, 2010). The model uses the effective cross-section method with zero-strength layers for structural fire design and accounts for different temperature gradients in the CLT members.

Full-scale testing and fire performance is summarized in separate testing performed by Frangi and Fragiacomo. A summary of fire testing and numerical analysis results is presented by Frangi (Frangi et al. 2008c). Results indicate that the fire performance of CLT panels depends on the behavior of single layers, accounting for delamination or fall-off.

Fire testing of unprotected and protected CLT panels was performed to establish the fire performance of panels subjected to out-of-plane loading. Results were compared to finite-element models used for sequential thermal and structural analysis to evaluate the model accuracy. Results indicate failure times of $99 \mathrm{~min}$ and $110 \mathrm{~min}$ for unprotected and protected CLT panels, respectively, and good agreement with the finite-element models (Fragiacomo et al. 2012a).

A summary of fire testing on 5-layer CLT floor panels is summarized by Fragiacomo (Fragiacomo et al. 2012b). Testing results indicated that numerical predictions for CLT panel performance proved to be accurate for predicting fire resistance.

Testing on unloaded CLT members was performed by FPInnovations in Canada using exposed CLT and CLT protected by gypsum board panels (Craft, Desjardins, \& Mehaffey, 2011). Results confirmed existing charring rate values for CLT panels, and demonstrated that gypsum board protection delays the onset of charring and combustion for the protected CLT panels below.

A series of eight medium-scale fire tests using standardized and non-standardized fires was performed to evaluate the performance of CLT floors. Testing assessed charring rate, temperature profile, deflection, gypsum protection and overall fire resistance (Aguanno, 2013). Results were used to develop a numerical model that is intended to assess fire resistance of CLT floors for any possible design fire or structural load.

Additional testing on CLT walls and panels was performed to demonstrate the performance of loaded CLT assemblies (Osborne \& Dagenais 2012). Testing also considered the effect of gypsum board protection for CLT panels, as scenarios included protected and unprotected CLT. Results indicate that the greater the depth of the section (3, 5 or 7 layers), the greater the fire resistance.

Additionally, gypsum board protection was shown to also increase the fire resistance time. Discussion on performance of gypsum board protection and charring rates is also provided (NRCC, 2013).

Full-scale fire testing for post-tensioned timber frame assemblies has primarily been performed in New Zealand, with summaries provided by Spellman (Spellman 2012) (Spellman, Carradine, Abu, Moss, \& Buchanan, 2012). These assemblies consist of large timber sections with embedded steel tendons that provide increased structural strength. While the timber sections provide inherent fire resistance due to their depth, it is important that sufficient protection be provided to post-tensioned connection elements to maintain stability in fire.

As the understanding of fire performance of engineered timber products increases, innovative solutions seek to combine timber with conventional materials to optimize structural design. Timber-concrete composite floor systems offer the benefits of heavy timber performance, while having a concrete topping that provides non-combustible fire separation and acoustic performance (O'Neill 2014).

Fire testing has evaluated different designs for timberconcrete systems (O'Neill 2009) (O'Neill, 2011), and existing systems have been shown to behave well in fullscale fire tests (O'Neill, Abu, Carradine, Spearpoint, \& Buchanan, 2012).

In October 2000, a large gymnasium fire in a glulam structure prompted a series of tests by Waseda University in Tokyo, Japan. The tests involved exposing glulam partition walls to a constant heat exposure from a propane burner to better understand the fire performance of glulam partition walls (Nam, Hasemi, Kagiya, \& Harada, 2002).

A first exposure test resulted in charring of the wall, with no significant combustion occurring on the member. The second exposure, approximately 2.5 times more severe, resulted in full panel burnout, consistent with expected conditions within the gymnasium. Charring rates were recorded for both tests and were shown to be consistent with literature values and estimates for the case study fire.

A full-scale fire test of a 3-story CLT building was performed in 2008 to evaluate the fire performance of 
a CLT building with gypsum board protection and no sprinklers (Frangi et al. 2008a). The test simulated a standard residential fuel load and evaluated temperatures in adjacent fire compartments, both to the side and above the fire room. The fire room consisted of 3.4" [85 mm] CLT wall panels protected by two layers of 0.5 " [12 mm] gypsum board. The floor and roof included 5.6" [142 mm] CLT panels with one layer of 0.5 " [12 $\mathrm{mm}$ ] gypsum board. The fire was allowed to burn a full $60 \mathrm{~min}$, at which point it was manually extinguished.

Intense burning consistent with flashover occurred about 6-7 $\mathrm{min}$ into the fire growth (Frangi \& Fontana 2005). This behavior was consistent with results in additional tests performed by Hakkarainen (Hakkarainen 2002). Findings indicate that flame spread and elevated temperatures were restricted to the room of fire origin. The study also suggested that protecting the timber structure with non-combustible gypsum board resulted in minimal damage to the CLT structure.

\section{Connections}

While there are many different types of timber connections, these can largely be classified into groups: primarily timber and steel connections. Fire performance of timber connections is similar to that of timber itself, with the potential for increased charring due to gaps in the connection. As such, fire testing data is focused on steel connections, which generally consist of screws, bolts, nails, fasteners and plate connections.

Several references provide overviews of fire testing data and performance of steel connections in timber (Austruy, Fragiacomo, Moss, \& Buchanan, 2007) (Lau, 2006) (Gerard, 2010). Embedded connections such as screws, nails and bolts tend to demonstrate better fire performance than fasteners and plate connections. This is due to the amount of steel area that is exposed to high temperatures, as steel strength rapidly decreases with increase in temperature (Milke, 2002).

The greater the steel area exposed to high temperatures, the worse the connection performance in fire. Accordingly, fasteners and plates tend to fail more quickly than nails, plates and bolts, which are generally embedded, and thus protected, by the structural timber elements (Noren, 1996) (NRC, 2003).

Given the strength loss at elevated temperature in steel, protecting steel connections in timber is critically important to maintaining stability in fire conditions. This can be achieved using gypsum board or other passive fire protection means, including embedding connections in timber sections, or providing proprietary products (Ostman 2010) (Frangi 2012).

Standardized tests were performed to evaluate the fire performance of unprotected and protected, or exposed and unexposed, steel plates and develop a finite element model to predict the fire resistance of steel plate connections (Erchinger, Frangi, \& Mischler, 2006). Exposed steel plates were placed on the exterior of a timber section and connected with dowels through the timber member. Unexposed steel plates, also called slotted plates, were embedded in the timber section and then connected by dowels through the section.

Results demonstrated that the slotted plates display significantly better fire resistance than exposed plate connections. Embedding the steel plate provided a layer of timber protection that reduced the exposed area of steel to high temperatures. Testing results were then used to develop the finite-element model, which showed good agreement with fire testing.

Testing performed by Peng evaluated the performance of bolted connections in timber when subjected to the standard time-temperature fire curve. Tests involved both exposed and unexposed bolted steel plate connections, and considered the effects of a single layer of either gypsum board or plywood protection (Peng et al. 2012a).

Exposed bolted steel plate connections performed the worst, due to the rapid heating with exposure to high temperatures. Providing a single layer of gypsum board was shown to nearly double the fire resistance time, with nearly a $50 \%$ increase for plywood protection. Additionally, fire resistance was shown to improve with increase in wood section width and decrease in the applied structural loading.

Results from testing were used as part of a second phase of research designed to develop a model for calculating the fire resistance of bolted connections (Peng et al. 2012b). A strength-reduction model was developed to calculate the load-bearing capacity of bolted connections for given temperature profiles. Comparisons with experimental tests showed good agreement for predicting the fire resistance of bolted timber connections.

Additional fire testing of bolted connections was performed by Chuo, Austruy and Moss (Chuo, Buchanan, \& Moss, 2007) (Austruy, Fragiacomo, Moss, \& Buchanan, 2007) (Moss, Buchanan, Fragiacomo, Lau, \& Chuo, 2009). Results of the standardized fire testing supported the results of previous tests in bolted connections. Reducing the exposed area of steel connections results in greater fire resistance times for the bolted connections.

Innovative connection design has also been tested utilizing hybrid connections between steel and epoxy to create epoxy-grouted steel rod connections in heavy timber. Fire testing performed at the University of Canterbury indicates that increases in steel rod temperature results in loss of connection strength (Lie, 1977) (Buchanan \& Moss 1999) (Harris, 2004) (Gerard, 2010). Furnace testing using standardized fire curves provides failures times for the different timber connections to demonstrate 
how modifications to the timber connection affect the fire performance.

Planned testing at Carleton University will evaluate the fire performance of timber connections with exposure to the standard fire. This data will be used to develop and validate a 3-D heat transfer model to predict temperature distribution through hybrid timber connections (Hadjisophocleous, Wasan, \& Ali, 2012). The model is intended to evaluate timber connection performance to resist experimental time-temperature curves.

Testing of timber connections is primarily restricted to the standard fire curve to allow comparisons in fire resistance to identical fire exposures. However, several studies have utilized experimental time-temperature curves to better understand connection performance.

Experimental testing of connections is generally characterized by allowing a timber connection to heat in an oven to a constant temperature. Heating regimes for testing range from ambient temperature $70{ }^{\circ} \mathrm{F}\left[20{ }^{\circ} \mathrm{C}\right]$, to elevated temperatures of less than $570{ }^{\circ} \mathrm{F}\left[300{ }^{\circ} \mathrm{C}\right]$. Heating at increments up to $570{ }^{\circ} \mathrm{F}\left[300{ }^{\circ} \mathrm{C}\right]$ are intended to better understand connection performance with increase in temperature prior to charring.

Testing performed by Chuo evaluated the strength of bolted connections in LVL with increase in temperature. Connection types included single-bolt configurations involving exposed steel plates connecting wood bolts, and steel plates protected by wood elements (Chuo, Buchanan, \& Moss, 2007). The tests compared connection strength at ambient temperature with strength in fire tests with exposure to temperatures ranging from $70{ }^{\circ} \mathrm{F}\left[20^{\circ} \mathrm{C}\right]$ to $480{ }^{\circ} \mathrm{F}\left[250{ }^{\circ} \mathrm{C}\right]$.

Results of experimental oven testing indicate a fairly constant rate of strength loss with increase in temperature. In most cases, approximately $50 \%$ of structural strength at ambient temperature is retained at temperatures up to $390{ }^{\circ} \mathrm{F}\left[200^{\circ} \mathrm{C}\right]$. This was consistent for both the exposed and unexposed steel plate bolted connections.

Additional testing of bolted connections in LVL was performed by Austruy (Austruy, Fragiacomo, Moss, \& Buchanan, 2007). The experimental setup was identical to Chuo, with exposed and unexposed steel plate connections and an oven heating testing regime from ambient up to $480{ }^{\circ} \mathrm{F}\left[250{ }^{\circ} \mathrm{C}\right]$. However, connections were tested with multiple bolts in bolt groups as opposed to single bolts.

Similar to previous results, as the temperature of bolted group connection assemblies increased, there was a marked decrease in strength. Results indicate a decrease of approximately $40 \%$ up to $210^{\circ} \mathrm{F}\left[100{ }^{\circ} \mathrm{C}\right]$, with constant strength until $390{ }^{\circ} \mathrm{F}\left[200{ }^{\circ} \mathrm{C}\right]$. Connection strength was shown to rapidly decrease beyond $390^{\circ} \mathrm{F}\left[200^{\circ} \mathrm{C}\right]$.

Results from experimental testing of bolted connections in LVL were used by Moss to develop a prediction method for the time to failure of bolted connections when exposed to fire (Moss, Buchanan, Fragiocomo, \& Austruy, 2010). This prediction method was evaluated against further experimentation of single-bolt connections involving exposed and unexposed steel plates.

Results indicate that exposed steel connections demonstrated the most rapid strength loss with increase in temperature. Test results at elevated temperature were then used to develop a simplified design approach that predicts connection strength based on bolt temperature.

Testing was also performed using multiple oven heating regimes for epoxied connections in LVL (Harris, 2004) (Gerard, 2010). Assemblies involving steel rods grouted in LVL sections using epoxy were tested for ultimate strength at ambient temperature. Epoxy grouted steel-timber connection assemblies were also placed in an oven and heated to a range of temperatures from $120^{\circ} \mathrm{F}\left[50{ }^{\circ} \mathrm{C}\right]$ to $570{ }^{\circ} \mathrm{F}\left[300{ }^{\circ} \mathrm{C}\right]$. Results from the oven and cooled testing indicate strength loss at elevated temperatures, with about $50 \%$ strength retained beyond $210^{\circ} \mathrm{F}\left[100{ }^{\circ} \mathrm{C}\right]$ (Gerard, 2010).

A second series of tests involved heating the connection assemblies and allowing them to cool to ambient temperature prior to testing. This was intended to better understand post-fire performance of epoxied connections. Generally, results indicate that ambient strength is maintained when the connection is allowed to cool to ambient temperature. In some cases, the strength after cooling actually increased compared to ambient conditions.

\section{Contribution of CLT to room fires}

At present, the contribution of CLT to room fires is seen as a key issue that has limited the development of timber buildings in some countries. Previous fire testing (Frangi et al. 2008a) (Osborne \& Dagenais 2012) (McGregor, Hadjisophocleous, \& Benichou, 2012) has shown that exposed timber has the potential to contribute to the fuel load in compartment fires and can result in compartment conditions with increased burning rates and greater temperatures.

Of significance is the work by McGregor (McGregor, Hadjisophocleous, \& Benichou, 2012) in which five fire tests carried out, using propane and furniture fires with CLT panels in protected and unprotected configurations. Test 5 was the fully exposed fire and showed that the decay in HRR was very slow and the temperatures did not decay for the 1-h test.

Primary conclusions of the testing regime include:

- With plasterboard concealing the CLT, there was no contribution of the CLT to the room fire or any influence.

- Where the CLT was unprotected, the CLT panels contributed to the fire load and increased fire growth rates and energy release rates. 
- Peak compartment temperatures are not significantly impacted and compartment temperatures are directly related to the slow decay in HRR.

- After the fire was extinguished, charring continued to occur behind the plasterboard.

Results of testing suggest the following conclusions for delamination behaviour:

- When delamination occurred, the fire burned at a high intensity well after the combustible contents in the room were consumed by the fire.

- CLT increased the room energy release by about $160 \%$.

- The exposed CLT results in prolonged higher compartment temperatures that are higher than the ISO834 curve for the decay period (see Fig. 4 below).

When charring advanced to the interface between the CLT layers, the polyurethane (PUR) based adhesive failed resulting in delamination, as would be expected. The delaminated wood then falls into the compartment (mainly from the ceiling) and contributed to the fire load and the exposed uncharred timber increased the intensity of burning and duration of the fire and can produce a second flashover.

The exposure of the unburnt CLT results in a faster char rate initially (as seen in all CLT fire tests) of up to $1.67 \mathrm{~mm} / \mathrm{min}$ at the ceiling, before returning to normal charring rate. Char depths vary within the compartment and where measured, but average out from $0.63 \mathrm{~mm} / \mathrm{min}$ to $0.66 \mathrm{~mm} / \mathrm{min}$, so very consistent with the Eurocode 5 char rate of $0.65 \mathrm{~mm} / \mathrm{min}$.
Observations showed that the flaming and the charring will self-extinguish, but the tests were not prolonged enough to prove this for fully exposed compartment.

\section{Traveling fires}

Recent research has considered the potential impact of traveling fires in building compartments. While traditional methods assume uniform burning and temperature in a fire compartment, a traveling fire scenario considers that burning is limited to a specific area at a given time, with elevated temperatures remote from the fire (SternGottfried, 2011).

The concept of traveling fires has been shown to be more realistic for large, open plan floor plates. Smaller fires travel across a floor plate for long periods of time with relatively low compartment temperatures, whereas larger fires have hotter compartment temperatures, but for shorter durations. This behavior can have a considerable impact on the structural response at high temperatures.

Special consideration is given to the fuel load within the fire compartment. This is often characterized based on occupancy type and any additional fire hazards. The potential for contribution of combustible linings should be considered.

The use of traveling fire scenarios has been shown to have considerable impact on the structural response with exposure to high temperatures. As a result, it is recommended for modern, open plan buildings, and is intended for structural analysis and design for fire safety and structural fire design, alike.

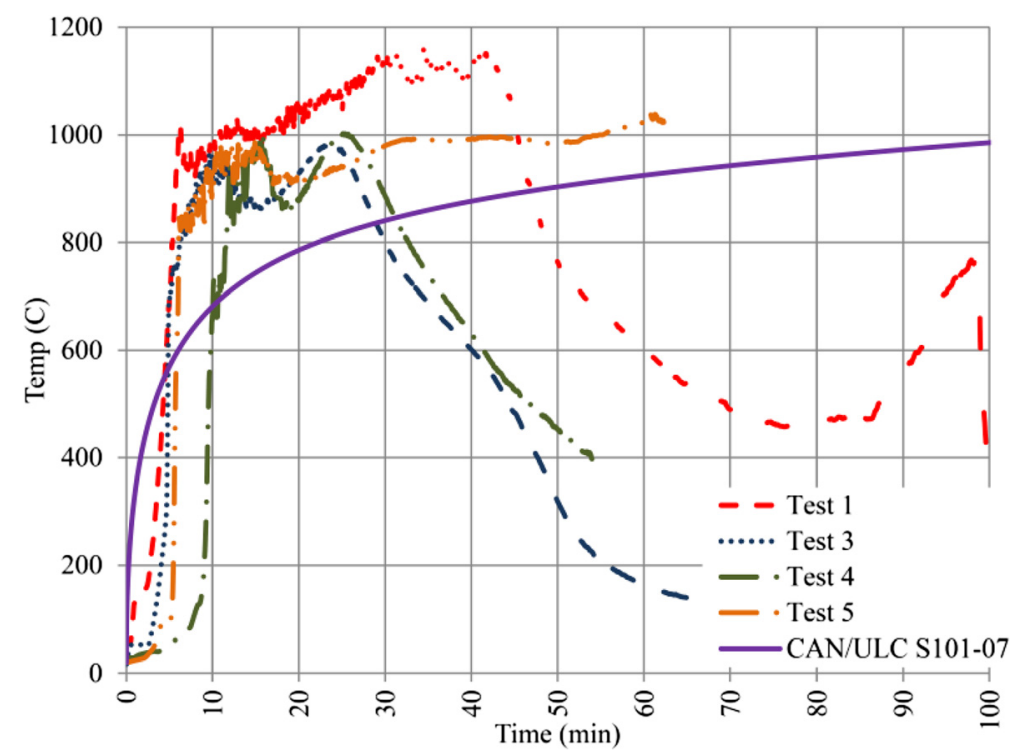

Fig. 4 Caption showing temperatures throughout the fire duration (McGregor, Hadjisophocleous, \& Benichou, 2012) 


\section{Guidance - multi-story timber construction}

A number of existing design guides are available that focus on multi-story timber construction. These typically highlight the advantages of tall timber construction and focus on structural information, including design and detailing. Issues such as fire safety, acoustics and floor vibration, are often presented as a basic introduction.

Prescriptive design guidance on multi-story timber buildings is available in many countries. This includes Eurocode 5: Design of timber structures Part 1-1 (BSI, 2004) in the UK, and the National Design Specification (NDS) for Wood Construction (AWC 2012) in the United States. These documents provide design guidance for stability, focusing on structural design and detailing, but also discuss fire safety.

One of the primary guidance documents was published in 2003 by the BRE (Grantham \& Enjily, 2003). While this document touches on fire safety aspects of timber buildings, the focus is on existing testing and designing for structural safety. This includes a summary and discussion of the Timber Frame (TF 2000) project, including outcomes of full-scale fire tests of a six-storey light timber frame building, and highlighting fire safety and structural performance issues.

Summaries of multi-story timber design guidance are provided in multiple documents (Crespell \& Gagnon, 2010) (WoodSolutions 2013d) (WoodWorks 2012) (Wells, 2011). These provide brief overviews of the many aspects that need to be considered for multi-story timber design, including technical design for structural and fire safety.

North America has produced several guidance documents specifically for multi-story design of CLT Buildings. Considerable research and testing performed by FPInnovations has led to the development of CLT Handbooks that can be used for prescriptive building design in the United States and Canada (Karacebeyli \& Douglas, 2013) (Gagnon \& Pirvu, 2011). These documents discuss a wide spectrum of multi-story timber design elements ranging from manufacturing and structural design, to fire and environmental performance.

Prescriptive design guidance for fire safety in timber buildings is internationally available in a number of documents. Eurocode 5: Design of timber structures Part 12 in the UK (Konig, 2005) (BSI, 2004) and the SFPE Handbook and American Wood Council in the US (White 2002) (AWC 2003) provide design guidance for fire safety in timber structures. These documents focus on structural fire safety, but emphasize the significance of other aspects of fire safety including design fires, fire dynamics and fire separations.

Design guidance from New Zealand provides a thorough summary of structural design for fire safety in all types of buildings, including a discussion of fire safety in timber structures (Buchanan 2001).
Information specific to timber frame buildings is available in additional guidance from Buchanan (Buchanan 2011). Fire performance of timber buildings, connections and behavior is presented, in addition to fundamentals of fire dynamics.

Summaries of fire safety in timber buildings are also published by multiple timber initiative groups across the world (WoodWorks 2011) (Maxim et al. 2013) (Dunn, 2010) (White 2012). These provide descriptions of many of the fire safety risks unique to timber design, as well as design solutions. The initiative websites provide an abundance of background and technical information to further understand the performance of timber buildings. See Section 2.3.2 for additional details on timber initiatives.

In addition to fire safety summaries, design equations for calculating fire performance and resistance of timber buildings are provided in multiple documents (CWC, 1996) (Frangi \& Fontana 2010) (AWC 2003). These allow a designer to quantify the performance of the structure in addition to identifying and appropriately mitigating potential hazards.

One of the most recent technical guidelines that focuses on fire safety in timber buildings was released in 2010 as a technical guideline for Europe (Ostman 2010). The guideline is based on a large body of empirical testing performed by SP Tratek and a number of universities and organizations across Europe. An overview of timber structures, including structural and fire safety considerations for connections, service penetrations and structural elements are provided. The guide also includes a discussion of fire protection strategies and performance based design intended to enable design and approval of timber structures for fire safety.

As previously discussed, timber construction is most vulnerable to fire during construction. Several documents have been published that provide guidance for fire safety of timber structures during construction (UKTFA, 2012) (Garis \& Clare, 2013) (TRADA, 2012) (WoodWorks 2010). Generally, guidance recommends providing appropriate separation distances between the construction site and adjacent buildings. The use of 24-h fire and security watches, in addition to heat and smoke alarms, and even temporary sprinklers, is also suggested.

Numerous studies on the fire safety risks and hazards of tall timber construction identify the key challenges to design, for which engineered approaches may provide solutions (Frangi et al. 2008b) (Frangi \& Fontana 2010) (Osborne \& Dagenais 2012). This is evidenced by recent design guides and technical studies that discuss performance based solutions that can be used to demonstrate safety in tall timber buildings.

A user-friendly matrix is available online that demonstrates where engineered solutions may be necessary for approval (WoodWorks 2013). This matrix allows a user to 
check characteristics of a building design against the prescriptive code to determine where an engineered solution may be necessary, or a performance based solution could be used.

The technical guideline for Europe describes the basic principles for fire risk assessment principles and performance based design. This includes fire safety engineering design, analytical approaches and calculation, design fires and statistics (Ostman 2010). While the design guide document is focused on timber design, the guidance on performance based solutions can be applied to all building types. This allows a designer to propose an engineered solution using fire risk assessment principles to comply with the prescriptive regulations.

In Canada, a technical and practice bulletin combines both prescriptive and engineered solutions to meet an equivalent level of safety required by the building code (APEG, 2011). This document focuses on solutions for structural and fire safety strategies for Canadian mid-rise residential buildings.

Australian guidance includes a series of technical documents intended to provide performance based design solutions for tall timber buildings (WoodSolutions (2013a)) (WoodSolutions 2013a) (WoodSolutions 2013b) (WoodSolutions 2013c). While these documents focus on fire safety information for CLT structures, they also discuss design strategies for building components including facades and internal linings.

Guidance in Canada provides a technical guide for the design and construction of tall timber buildings (Karacabeyli \& Lum, 2013) (Karacabeyli \& Lum, 2013). This design guide is unique in that it is intended to follow performance based design philosophies utilizing alternative solutions to meet the life safety objectives of the prescriptive code. The technical guide discusses recommendations for redundancy and resiliency and emphasizes a multi-disciplinary approach with reference to technical information.

\section{Gap analysis}

The literature review seeks to evaluate the current knowledge of tall timber construction, identify gaps in knowledge, and reflect on the gaps that, if fulfilled, will provide a better understanding of the potential fire safety performance of tall wood buildings. Timber as a building material, whether used as light timber framing or heavy timber construction, is very well-studied and understood with regard to fire, given its use as a multi-story building material for well over 500 years.

The gap analysis is intended to identify gaps in current knowledge that are required to be better understood to advance the performance of tall timber buildings. As would be expected with any new technology, the many new and innovative timber design methods now being developed, including CLT, composite timber structures and post-tensioning of timber, introduce gaps in knowledge related to fire safety. Readers should note that many "gaps" in knowledge are related directly to the new technology of engineered timber products that have resulted from the use of CLT.

\section{System-level testing}

While fire test regimes consider exposure to the standard and experimental fires, testing is generally limited to single-element tests. This involves fire testing of a connection or element in isolation from the rest of the structure. Single-element fire tests are generally simple tests used to better understand fire performance a single structural element, assembly or connection type. They are useful for a general understanding of that element in isolation. However, they are limited in that they do not capture the fire performance of a structural system assembly, or frame action, as would occur in completed buildings. System-level fire testing of frames and assemblies has the potential to achieve greater understanding of the fire performance of structural systems exposed to high temperatures.

For multi-story timber buildings, particularly frame buildings (post and beam construction), several tests have considered multiple load ratios to evaluate the fire performance of specific timber elements (O'Neill 2009) (Fragiacomo et al. 2012b) (Osborne \& Dagenais 2012). Generally the greater the load ratio, the worse the fire performance.

Additional analysis and testing will improve the understanding of the effect of loading on fire performance, and also the impact of load-sharing (frame action) on timber elements. This is important as the current testing is based on single elements with fixed load ratios. In a real fire situation, a building will involve heating of multiple timber elements. The load-bearing elements are expected to "load-share", or "redistribute" in a method that is not easily predicted in simple fire testing.

Understanding this frame action is expected to result in fire performance that exceeds current design estimates, as is the case for steel frame buildings. This issue of load-sharing during a fire event may also be relevant for panel type buildings, such as those using CLT, where floor and wall loadings may result in load redistribution and sharing as a fire continues through to burn-out.

For example, fire tests with exposed steel framing subjected to natural fires at Cardington in the UK is one such example of system-level testing (Usmani, et al., 2000). This program of fire testing improved the understanding of structural performance of exposed steel systems in natural 
fire conditions, including the consequences to the structure during and following a fire scenario.

A comparable system-level fire test for a multi-story timber structure would have the potential to lead to a significant step-change in the understanding and acceptance of multi-story timber frame buildings. In the same way that the Cardington tests resulted in a step-change in the acceptance of exposed structural steel, a multistory building test with full burn out may assist with the acceptance of large timber buildings.

\section{Transient fire testing}

As previously discussed, time-temperature curves in fire testing can be characterized as exposure to the standard fire or experimental fire curve. The standard fire curve consists of rapid fire growth and continuous heating for the duration of the test (Buchanan 2001). An experimental fire curve is considered to be any other non-standardized time-temperature curve.

Experimental fire curves generally consist of uniform heating or natural fire regimes that are discontinued at a specific point. These tests are valuable for furthering the understanding of structural performance at elevated temperatures. However, they do not include the final phase of fire development, referred to as the decay phase.

In the decay phase, compartment temperatures cool as the fire intensity decreases. Generally the most structurally severe fire conditions are assumed to occur during peak heating. However, testing of exposed steel structures has shown that structural behavior in the cooling phase can result in structural failure (Usmani, et al., 2000).

While the focus of fire testing is on the fire performance of timber elements and connections with exposure to elevated temperatures, consideration of the decay phase and cooling of structural assemblies would help to better understand structural performance.

\section{Use of composite assemblies}

Composite assemblies in timber buildings have been used in many forms in the past, including steel plates to assist with timber beams, tension rods in timber trusses and post-fire rehabilitation efforts to strengthen or reinforce timber members.

Many modern designers view the use of composite assemblies as useful to satisfy the structural demands of tall timber structures. Combining the benefits of multiple construction types, primarily steel, concrete and timber, maximizes material properties and allows a designer greater flexibility for design (Green, 2012).

One of the areas of significant further development is the use of timber-concrete composite floor systems. Composite timber and concrete floors offer potential for timber buildings as an economic and efficient flooring system. They can provide the structural soundness, acoustics and fire resistance, using the benefits of concrete, combined with a lightweight timber sub-structure. This has led to the use of timber-concrete systems in multiple buildings, including Life Cycle Tower (Wurm, Gockel, \& Unger, 2012) and the Bullitt Center (Newcomb, 2012).

Fire testing of timber-concrete composite floors is limited, but recent fire testing performed by O'Neill has improved the understanding of fire-performance of timber-concrete composite systems (O'Neill 2014).

Current feasibility designs for tall timber buildings seek to maximize the use of composite assemblies to enable the construction of taller timber buildings due to the efficiencies offered. The use of composite assemblies in timber buildings can be utilized to enable the design of taller timber buildings. However, it is important to have an appropriate understanding not only of the structural performance of these innovative systems, but also the fire performance of the hybrid assemblies.

Other innovative composite construction methods, such as combining steel and timber to gain additional tensile and compressive strength through a combined building element, will also require fire testing to understand the fire resistive properties.

\section{Connections between timber components and composite assemblies}

Current understanding of the fire performance of connections in timber buildings has benefitted from a number of fire tests. Connections involved in fire testing range from nails and bolts, to plates and steel rods and epoxy adhesive. Fire testing also includes results from standard fire testing of composite elements with timber-concrete composite floors.

Results from fire testing of steel connections indicate the importance of providing protection for exposed steel elements. Fire protection strategies generally involve providing a protective layer of gypsum board over exposed structure and connection elements. However, this is neither an aesthetic, efficient or cost-effective solution for construction.

Steel elements for connections can also be embedded within the structure. While this may be beneficial for fire safety, it is not efficient for construction and is also costly. Embedding steel plate connections can also have a potential impact on the structural component size. Elements may need to be over-sized to provide the appropriate thickness and protection from heating. Workmanship and protection of such connections is important for demonstrating predic and reliable fire performance in timber connection applications.

Thus, there is more work to be carried out in the understanding of fire protection of connections, given that 
connections that are most efficient for structure and constructability may perform poorly in fire. Additionally, those connections that perform well in fire may be expensive or structurally inefficient.

New timber technologies such as CLT have developed relatively effective and fire-safe connections. These often utilize long screws embedded in the solid panels. This offers good fire performance, as the screw head is a relatively small exposed area for heating in fire and the large screw length is protected within the solid timber.

Given the recent development of tall timber structures, a designer must consider the types of connections that will be used and their overall effectiveness and cost. With the new emerging timber technologies, such as CLT box beams, post-tensioned timber and timber-concrete composite floors, efficient and fire-safe connections need to be developed to allow the systems to be easily constructed, structurally-efficient and cost-effective.

Additionally, the ability to understand and predict fire performance of connections in structural systems and composite assemblies is critical to demonstrating structural safety in fire.

\section{CLT Delamination/Char fall-off}

Previous CLT fire testing has resulted in delamination and char fall-off when exposed to fire conditions. This can occur where unprotected CLT panels are exposed to the fire (not all CLT is exposed and in some buildings the CLT is covered with gypsum plasterboard for fire protection or acoustic reasons). This is not an unexpected failure mode and occurs mainly when CLT is located as a floor and exposed to fire from the underside.

Delamination is shown to occur when the charring layer advances to the interface between layers in CLT panels (Osborne et al. 2012). Char fall-off can occur when charred timber, or fire protective panels, falls-off and exposes the structural wood below to high temperatures. This behavior is unique to fire testing of CLT panels and is not apparent in other engineered timber products.

CLT element charring and separation from the assembly can result in increased charring rate and fire intensity (Frangi et al. 2008c). This has the potential to increase the fire temperature and burning rate within the compartment. While this is part of the CLT burning process, this behavior will be better understood as more tests are carried out.

Additional fire testing would seek to characterize the fire performance of CLT elements, to not only predict the conditions for if or when delamination or fall-off may occur, but also understand the impact on the fire compartment and structural assembly when this does occur. The aim is to better account for the delamination and better predict how this impacts the CLT fire resistance rating.

\section{Penetrations for services}

Penetrations in building elements are generally provided for mechanical, plumbing, air-conditioning and electrical services throughout a structure. Openings in elements are typically provided for pipes, cables, ducts and other services for business operations and building occupants. These penetrations require fire stopping where these services pass through a fire rated assembly.

Appropriate fire-stopping at penetrations is necessary to contain fires and prevent smoke and fire spread to adjacent areas. Fire testing of penetrations is used to test the following conditions (Kampmeyer, 2008):

- Through-penetration firestop systems - used to seal openings through rated walls and floors;

- Perimeter fire containment systems - used to seal openings between floors and curtain walls; and

- Joint systems - used to seal openings where two elements of construction intersect as joints.

Typically, fire-stopping at penetrations and openings pass through non-combustible construction. The seal at the penetration where the structure and fire-stopping meet is non-combustible and assumed to not be affected by exposure to high temperatures. In combustible elements, such as timber, potential charring at the seal between the structure and fire-stopping could compromise the firestopping effectiveness. This behavior may impact the fire-stopping fire performance.

The sealing of penetrations is achieved through the installation of proprietary products such as dampers, collars, mastics, foams, pillows and similar products. The companies that produce these products test them to a relevant standard, which varies from country to country.

The issue of penetration seals that can be used in timber construction is an area requiring work as it requires:

- Test standards to be altered to allow for the tests to be carried out with combustible bases or substrates, where the test standard only permits testing to be carried out with non-combustible substrates, such as concrete or gypsum plasterboard; and

- Requires manufacturers to test a range of products that can then be used in floors and walls for timber buildings.

Fire-stopping for penetrations and openings in combustible structures would have to achieve the performance requirements to be approved for use in timber structures. This requires that the entire fire-stopping assembly, including the product and combustible material it penetrates, 
achieves the appropriate performance when exposed to the fire testing protocols.

\section{Timber façades}

As the use of timber increases, architects and designers have been seeking additional applications for timber as an alternative building material. One potential use is the application of timber to building façades.

As a combustible material, there are several hazards associated with combustible façade design (WoodSolutions, Alternative Solution Fire Compliance: Facades, 2013):

- Façade ignition and fire propagation;

- Fire spread through openings in external walls; and

- External fire spread between buildings and parts of buildings.

Ignition of combustible material could potentially lead to internal and external fire spread. Fire testing of façades is limited to a number of cases, and additional testing is necessary to determine the potential impact on both the safety from fire and structural failure principles (Hakkarainen \& Oksanen 2002).

One potential mitigation strategy is the application of fire retardant on a combustible timber façade. However, research with fire retardant applications that improve fire resistance and flame spread rating have proven inconclusive (Ostman \& Tsantaridis 2006). Additionally, there are durability concerns with topical applications due to exposure to weather, damage, or general wear and tear. Additional research is necessary to clarify if this has a potential effect on fire performance of combustible façade assemblies.

Given that timber façade design is a relatively recent innovation, establishing the fire performance of the structural façade assembly is necessary to demonstrate fire safety. This includes not only evaluating the façade itself, but also the framing and connections that are necessary to maintain stability and compartmentation in fire conditions.

\section{Concealed spaces}

Concealed spaces within a building have the potential to result in fire spread throughout a structure. Fire incidents in timber frame buildings have highlighted the need for appropriate fire blocking within concealed spaces.

One benefit of heavy timber construction is the frequency of concealed spaces compared to light timber construction. Solid CLT panels and open plan post and beam framing has significantly fewer concealed spaces compared to light timber framing. Nonetheless, it is important to understand the consequences of a potential fire within a concealed space in a heavy timber structure.

There are few fire tests to understand how fire will spread through concealed spaces in heavy timber buildings. Further testing could be used to evaluate the potential for fire spread through compartments. Consequences have the potential to range from self-extinguishment to complete burnout of the entire structure.

A greater understanding is necessary to determine if a fire in a concealed space is a credible scenario, and potentially determine the appropriate fire protection solution to manage the risk to the structure and the building occupants.

\section{Contribution of exposed timber to room fires}

One of the primary challenges for the design of timber structures for fire safety is wood's combustible nature. In wood buildings, the timber structure can be assumed to contribute to the fuel load. While the literature review discusses several tests with exposed timber (Frangi et al. 2008a) (Osborne \& Dagenais 2012) (McGregor, Hadjisophocleous, \& Benichou, 2012), it is important to better understand what contribution exposed timber will have to room fire behavior - both qualitatively and quantitatively. This includes considering not only if timber makes a contribution, but evaluating by how much.

Previous testing has shown that structural timber elements can make a contribution to the room fire behavior (Frangi et al. 2008a), though this could be relatively insignificant. While charring has been shown to not have a significant effect on compartment fire dynamics, char fall-off has. This can occur where exposed CLT is used for walls and the underside of floors. When exposed CLT timber elements char and separate from the structure, they have the potential to contribute to the fuel load and result in increased fire temperature within the compartment. This behavior is unique to CLT structures, and is not apparent in other heavy timber construction types.

While the fuel load contribution from timber fall-off is assumed to occur late in the fire duration, it could have a potential impact on compartment conditions. Further testing is necessary to characterize this impact. This could include long duration burn-out tests to gain a better understanding. A change in fire compartment conditions could potentially impact the structural response for timber buildings exposed to high temperatures for long durations, and needs to be accounted for within the design.

Previous research indicates that the contribution of timber to a compartment fire can be heavily dependent on the amount of applied fire protection within the compartment. In general, the greater the amount of applied fire protection, the reduction in the contribution of timber to the room fire. A better understanding, and importantly quantification, of how applied fire protection 
impacts the timber contribution to the fire would be valuable. This information could be used as a basis for future design of timber compartments.

\section{Compartment burnout - self-extinguishment}

As previously discussed, fire testing has shown that timber has the potential to contribute to the combustible fuel load in a fire compartment, though the extent may be minor for post and beam type construction, it can be relatively significant for exposed CLT panels in panelized construction. Important aspects when considering the combustibility of the structure is to be able to:

- Establish if and when extinguishment may occur;

- Characterize the structural and fire compartment impact; and

- Be able to accurately predict the performance.

One method of evaluating the level of contribution is to allow a fire compartment to continue to burn without intervention. Results could be used to better understand the consequences of complete burnout of timber buildings, including evaluating the potential for acceptable self-extinguishment. This is assumed to occur when all the combustible contents have been consumed and the timber elements are able to maintain their load-carrying strength or provide acceptable compartmentation.

Previous testing on timber compartments has generally been performed for a finite fire testing period. Where testing is performed with exposure to the standard fire, the fire duration is usually measured in increments of $30 \mathrm{~min}$ to determine the fire resistance rating. In experimental test setups, such as natural fire tests, testing is often stopped at a pre-determined time.

One example of fire testing that was discontinued is natural fire testing in a light timber frame building. Fire extinguishment was pre-arranged with the fire department, as the test was intended to evaluate the potential for fire spread for a fire duration of 60 min only (Frangi et al. 2008a).

Fire testing in Canada simulated room contents in an unprotected CLT building assembly to evaluate the consequences of fire in exposed CLT buildings. Results indicated that fire in unprotected rooms continued to burn at high intensity even after the combustible contents were consumed. The fire was extinguished to prevent potential structural damage to the test room (McGregor, Hadjisophocleous, \& Benichou, 2012).

Additional fire testing is required to establish the extent of the contribution, the potential for self-extinguishment, and better understand potential credible fire scenarios in timber buildings. A greater understanding of the performance of timber structures in a complete burnout scenario could affect the fire resistance ratings required for a building. This could result in providing a greater level of fire protection for timber assemblies, or allowing timber to be exposed if the results are quantified.

\section{Risk communication}

An additional gap is the need for effective risk communication of these fire safety challenges to the general public. This involves using research, testing and studies such as this to educate about the fire safety challenges in timber buildings. Communicating results of fire performance in tall timber structures can potentially dispel preconceptions about safety in timber structures.

Industry groups are intended to provide technical information about tall timber buildings for architects, developers, engineers, code officials and other relevant building stakeholders. This includes structural design, detailing, environmental performance and other issues in addition to fire safety. Use of these mechanisms and other communication tools promote understanding of the safety concerns and protection measures associated with tall timber construction.

Effective risk communication is intended to allow society to make informed decisions about the fire safety challenges and fire protection strategies for tall timber buildings.

\section{Prioritization}

The gap analysis presents a number of issues for which greater research and understanding is necessary to better assess structural fire performance and credible fire scenarios.

While all these issues are considered to be important in achieving a greater level of understanding, the following three gaps are selected as having the greatest priority:

1) Contribution of Exposed Timber to Room Fires This gap is critical to not only better understand the implications of exposed timber on compartment fire dynamics, but also dispel potential myths and preconceptions regarding fire safety in timber buildings;

2) Connections Between Timber Components and Timber Composite Assemblies - Further understanding of connection performance is necessary to demonstrate safety for a whole structural assembly in fire. This includes understanding what types of connections designers can expect, but also how these new connections perform in fire conditions; and

3) Penetrations for Services - Understanding penetration behavior through structural elements is critical to achieving compartmentation and enabling the installation of building services for fire safety.

Note that the priority ranking has been selected based on previous research and discussions with a number of leading timber experts. 


\section{Summary and recommendations}

This study seeks to evaluate the current knowledge of tall timber construction, identify gaps in knowledge, and reflect on the gaps that, if fulfilled, will provide a better understanding of the potential fire safety performance of tall wood buildings.

The gap analysis seeks to identify the design and material gaps in knowledge that need to be explored to better understand the performance of timber as applied to tall buildings. The gap analysis discusses specific areas of research necessary to better understand the fire safety challenges in tall timber buildings.

Based on the resources presented in the literature review and gap analysis, recommendations for future research and testing include the following:

- Fire testing of new and innovative timber and hybrid solutions;

- Full-scale/large-scale fire testing of mock up tall timber frames;

- Natural fire testing in full-scale/large-scale tall timber frames;

- Economic analysis to quantify construction, operation and costs of tall timber buildings; and

- Emphasis on effective risk communication and education.

Ultimately, research, fire testing and greater experience with combustible construction has the potential to increase the understanding of fire safety challenges in tall timber buildings. However, it is the effective communication of this understanding to develop fire protection solutions to manage the risks and hazards that is critical to demonstrating fire safety in tall timber structures and supporting change to the prescriptive environment.

\section{Competing interests}

The authors declare that they have no competing interests.

\section{Authors' contributions}

$\mathrm{DB}$ and $\mathrm{RG}$ contributed equally to this paper. Both authors read and approve the final manuscript.

\section{Author details \\ ${ }^{1}$ Arup, 1120 Connecticut Avenue, Washington DC, NW 20036, USA. ${ }^{2}$ Arup, Level 10, 201 Kent Street, Sydney, NSW 2000, Australia.}

Received: 15 August 2014 Accepted: 27 May 2015

Published online: 11 June 2015

\section{References}

Aguanno M (2013) Fire Resistance Tests on Cross-Laminated Timber Floor Panels: An Experimental and Numerical Analysis. Carleton University, Ottawa, Canada

AITC (2012) Fire Resistance of Exposed Glued Laminated Timbers. American Institute of Timber Construction, Centennial, Colorado, USA

APEG (2011) Structural, Fire Protection and Building Envelope Professional Engineering Services for 5 and 6 Storey Wood Frame Residential Building Projects (Mid-Rise Buildings). APEGBC Professional Engineers and Geoscientists of BC, British Columbia, Canada
Austruy C, Fragiacomo M, Moss P, Buchanan A (2007) Fire Resistance of Timber Connections. Ecole Normale Superieure de Cachan, Cachan, France

AWC (2003) Calculating the Fire Resistance of Exposed Wood Members. American Forest and Paper Association, Inc., Washington, DC, USA

AWC (2012) National Design Specification for Wood Construction. American Wood Council, Leesburg, Virginia, USA

Babrauskas V (2004) Wood Char Depth: Interpretation in Fire Investigations. In: International Symposium on Fire Investigation. Fire Science and Technology Inc, Moreton-in-Marsh, UK

Barber D, Gerard R, Wolski A (2013) Fire Safety Challenges of Tall Wood Buildings. Fire Protection Research Foundation, Quincy, Massachusetts

Bregulla J, Enjily V (2004) Structural Fire Engineering Design: Materials Behaviour Timber. BRE Bookshop, Watford, UK

BSI (2004) Eurocode 5: Design of Timber Structures. British Standards Institution, London, UK

Buchanan A (2001) Structural Design for Fire Safety. John Wiley and Sons, West Sussex, UK

Buchanan A (2011) Timber Design Guide. New Zealand Timber Industry Federation, Christchurch, New Zealand

Buchanan A, Moss P (1999) Design of Epoxied Steel Rods in Glulam Timber. Pacific Timber Engineering Conference. PTEC, Rotorua, New Zealand

Chuo T, Buchanan A, Moss P (2007) Fire Performance of Connections in Laminated Veneer Lumber. University of Canterbury, Fire Engineering Research Report 07/4, Christchurch, New Zealand

Craft S, Desjardins R, Mehaffey J (2011) Investigation of the Behaviour of CLT Panels Exposed to Fire. In: Fire and Materials. Fire and Materials, San Francisco, California, USA

Crespell P, Gagnon S (2010) Cross Laminated Timber: a Primer. FPInnovations, Special Publication 52

CWC (1996) Fire Safety Design in Buildings. Canadian Wood Council, Ottawa, Canada

Dunn V (2010) Collapse of Burning Buildings - A Guide to Fireground Safety. Penwell Books, Tulsa, Oklahoma, USA

Erchinger C, Frangi A, Mischler A (2006) Thermal Investigations on Multiple Shear Steel-to-Timber Connections. 9th World Conference on Timber Engineering. World Conference on Timber Engineering, Portland, Oregon, USA

Forintek (2002) Wood-Frame Construction, Fire Resistance and Sound Transmission. Forintek Canada Corporation, Quebec, Canada

Fragiacomo M, Menis A, Clemente I, Bochicchio G, Ceccotti A (2012a) Fire Resistance of Cross-Laminated Timber Panels Loaded Out of Plane. J Struct Eng 139(12):145-159

Fragiacomo M, Menis A, Clemente I, Bochicchio G, Tessadri B (2012b) Experimental and Numerical Behaviour of Cross-Laminated Timber Floors in Fire Conditions. In: World Conference on Timber Engineering. WCTE, Auckland, New Zealand, pp 177-178

Frangi A (2012) Fire Resistance Assessment of Timber Structures. Workshop 'Structural Fire Design of Buildings According to the Eurocodes'. European Commission, Brussels, Belgium

Frangi A, Fontana M (2005) Fire Performance of Timber Structures under Natural Fire Conditions. In: Fire Safety Science Symposium 8. IAFSS, Beijing, China, pp 279-290

Frangi A, Fontana M (2010) Fire Safety of Multistorey Timber Buildings. Structures Build 163(4):213-226

Frangi A, Bochicchio G, Ceccotti A, Lauriola M (2008a) Natural Full-Scale Fire Test on a 3 Storey XLam Timber Building. World Conference on Timber Engineering, WCTE, Miyazakik Japan, June 2-5

Frangi A, Fontana M, Knoblock M (2008b) Fire Design Concepts for Tall Timber Buildings. Struct Eng Int 18(2):148-155

Frangi A, Fontana M, Knoblock M, Bochicchio G. (2008c). Fire Behaviour of Cross-Laminated Solid Timber Panels. Fire Safety Sci, 1279-1290.

Gagnon S, Pirvu C (2011) CLT Handbook - Canadian Edition. Library and Archives Canada Cataloguing in Publication, Quebec, Canada

Garis L, Clare J (2013) Fire and Safety Risks Posed by Wood Frame Residential Construction - An Evidenced Based Review, Large Wood Structures Symposium

Gerard R (2010) Fire Resistance of Connections in Pre-Stressed Heavy Timber Structures. University of Canterbury, Christchurch, New Zealand

Grantham R, Enjily V (2003) Multi-Storey Timber Frame Buildings - A Design Guide. BRE Bookshop, London, UK

Green M (2012) The Case For Tall Wood Buildings. mgb Architecture + Design, Vancouver, Canada

Hadjisophocleous G, Wasan S, Ali S (2012) Fire Performance of Timber Connections. NEWBuildS, Fredericton, Canada 
Hakkarainen T (2002) Post-Flashover Fires in Light and Heavy Timber Construction Compartments. J Fire Sci 20(2):133-175

Hakkarainen, T., \& Oksanen, T. (2002). Fire safety assessment of wooden facades. Fire Mater, 7-27

Harris S (2004) Fire Resistance of Epoxy-grouted Steel Rod Connections in Laminated Veneer Lumber (LVL). University of Canterbury, Fire Engineering Research Report 04/7, Christchurch, New Zealand

Hopkin D (2011) The Fire Performance of Engineered Timber Products and Systems. Loughborough University, Hertfordshire, UK

Kampmeyer J (2008) Penetration Sealing. In: A. Cote, Fire Protection Handbook. National Fire Protection Association, Quincy, Massachusetts, USA, pp 18:73-18:88

Karacabeyli E, Lum C (2013) 90 \% Draft of the Technical Guide for the Design and Construction of Tall Wood Buildings in Canada. FPInnovations, Pointe-Claire, Canada

Karacebeyli E, Douglas B (2013) CLT Handbook - US Edition. Library and Archives Canada Cataloguing in Publication, Quebec, Canada

King M (2007) Guidelines for Fire and Smoke Damage Repair. Restoration Industry Association (RIA), Rockville, Maryland, USA

Konig J (2005) Structural fire design according to Eurocode 5 - design rules and their background. 8th International Symposium on Fire Safety Science. IAFSS, Beijing, China, pp 147-163

Lane W (2001) Ignition, Charring and Structural Performance of Laminated Veneer Lumber (LVL). University of Canterbury, Fire Engineering Research Report 05/3, Christchurch, New Zealand

Lau P (2006) Fire Resistance of Connections in Laminated Veneer Lumber University of Canterbury, Fire Engineering Research Report 06/3, Christchurch, New Zealand

Lie T (1977) A Method For Assessing The Fire Resistance Of Laminated Timber Beams And Columns. Can J Civil Eng 4:161-169

Maxim P, Plecas D, Garis L, Clare J (2013) Taller Wood Buildings and Fire Safety. University of the Fraser Valley, British Columbia, Canada

McGregor C, Hadjisophocleous G, Benichou N (2012) Contribution of Cross Laminated Timber Panels to Room Fires. NEWBuildS, Fredericton, Canada

Milke J (2002) Analytical Methods for Determining Fire Resistance of Steel Members. In: DiNenno P (ed) SFPE Handbook of Fire Protection Engineering. Society of Fire Protection Engineers, Quincy, Massachusetts, pp 4:209-4:238

Moss P, Buchanan A, Fragiacomo M, Lau P, Chuo T (2009) Fire Performance of Bolted Connections in Laminated Veneer Lumber. Fire Mater 33:223-243

Moss P, Buchanan A, Fragiocomo M, Austruy C (2010) Experimental Testing and Analytical Prediction of the Behaviour of Timber Bolted Connections Subjected to Fire. Fire Technol 46:129-148

Nam D, Hasemi Y, Kagiya K, Harada T (2002) Role of Initial Burning Objects in the Fire Growth in a Large Enclosure-Experiments for the Investigation of a Recent Timber Gymnasium Building Fire. International Association for Fire Safety Science. IAFSS, Marne-La-Valee, France

Newcomb, T. (2012, June 20). Seattle's Silver Bullitt: A New Office Building Goes Ultra-Green. Retrieved May 17, 2013, from Time Magazine: http://science.time. com/2012/06/20/silver-bullitt/

Noren J (1996) Load-bearing Capacity of Nailed Joints Exposed to Fire. Fire Mater 20(3):133-143

NRC (2003) Timber Structures. NRC CNRC, Ottawa, Canada

NRCC (2013) Full-Scale Fire Resistance Tests on Cross-Laminated Timber. National Research Council Canada, Ottawa, Canada

O'Neill JC (2011) Design of Timber-Concrete Composite Floors for Fire Resistance. J Struct Fire Eng Special Issue 6th Int Confer Struct Fire SiF'10 2(3):231-242

O'Neill J (2009) The Fire Performance of Timber-Concrete Composite Floors. University of Canterbury, Thesis, Christchurch, New Zealand

O'Neill JA (2014) Modelling the fire performance of structural timber-concrete composite floors. J Struct Fire Eng 5(2):113-124

O'Neill J, Abu A, Carradine D, Spearpoint M, Buchanan A (2012) Modelling Prefabricated Timber Floors in Fire. In: World Conference on Timber Engineering. WCTE, Auckland, New Zealand, pp 227-228

Osborne L, Dagenais C (2012) Preliminary CLT Fire Resistance Testing Report 2012/2013. Final Report, Pointe-Claire, Canada

Osborne L, Dagenais C, Benichou N (2012) Preliminary CLT Fire Resistance Testing Report. FPInnovations, Pointe-Claire

Ostman B (2010) Fire Safety in Timber Buildings - Technical Guideline for Europe. SP Report 2010:19, Stockholm, Sweden

Ostman B, Tsantaridis L (2006) Innovative eco-efficient high fire performance wood products for demanding applications. SP Wood Technology, Stockholm, Sweden
Peng L, Hadjisophocleous G, Mehaffey J, Mohammad M (2012a) Fire Performance of Timber Connections, Part 1: Fire Resistance Tests on Bolted Wood-Steel-Wood and Steel-Wood-Steel Connectinos. J Struct Fire Eng 3(2):107-132

Peng L, Hadjisophocleous G, Mehaffey J, Mohammad M (2012b) Fire Performance of Timber Connections, Part 2: Thermal and Structural Modelling. J Struct Fire Eng 3(2):133-154

Ross R (2005) Post-Fire assessment of structural wood members. In: Ross R, Brashaw B, Wang X, White R, Pellerin R (eds) Wood and Timber Condition Assessment Manual. Forest Products Society, Madison, Wisconsin, USA, pp 29-46

Schaffer EC (1986) Strength Validation and Fire Endurance of Glue-Laminated Timber Beams. Forest Products Laboratory, Madison

Schmid J, Konig J, Kohler J (2010) Fire-Exposed Cross-Laminated Timber - Modelling and Tests. World Conference on Timber Engineering. WCTE, Trentino, Italy

Spellman P (2012) The Fire Performance of Post-Tensioned Timber Beams. University of Canterbury, Christchurch, New Zealand

Spellman P, Carradine D, Abu A, Moss P, Buchanan A (2012) Full-Scale Fire Tests of Post Tensioned Timber Beams. World Conference on Timber Engineering. World Conference on Timber Engineering, Auckland, New Zealand, pp 229-230

Stern-Gottfried J (2011) Travelling Fires for Structural Design. University of Edinburgh, Edinburgh, Scotland

TimberFrameFires (2011) Background. Retrieved August 1, 2013, from Timber Frame Buildings: www.timberframefires.co.uk

TRADA (2012) Fire Safety on Timber Frame Construction Sites. TRADA Technology, High Wycombe, Buckinghamshire, UK

Tsai W (2010) Charring Rates for Different Cross Sections of Laminated Veneer Lumber (LVL). University of Canterbury, Fire Engineering Research Report 10/5, Christchurch, New Zealand

UKTFA (2012) Design Guide to Separating Distances During Construction. UKTFA, Alloa, UK

Usmani A, Drysdale D, Rotter J, Sanad A, Gillie M, Lamont S (2000) Behaviour of steel framed structures under fire conditions. The University of Edinburgh, Edinburgh, Scotland

Wells M (2011) Tall Timber Buildings: Applications of Solid Timber Construction in Multistory Buildings. CTBUH J 1:24-25

White R (2002) Analytical Methods for Determining Fire Resistance of Timber Members. In: DiNenno P (ed) SFPE Handbook of Fire Protection Engineering, 3rd edn. Society of Fire Protection Engineers, Quincy, MA, USA, pp 4:257-4:273

White R (2004) Fire Resistance of Exposed Wood Members. In: 5th International Scientific Conference. Slovak Republic: Wood \& Fire Safety, Strbske Pleso, pp 337-344

White R (2006) Fire Resistance of Structural Composite Lumber Products. US Department of Agriculture, Forest Service, Forest Products Laboratory, Research Paper FPL-RP-633, Madison, Wisconsin, USA

White R (2009) Fire Resistance of Wood Members with Directly Applied Protection. Fire and Materials. Interscience Communications, San Francisco, California, USA, p 97

White N (2012) Tall Timber Construction: Fire Safety, Environmental and Cost Effectiveness. Fire Australia Conference and Exhibition. Fire Australia, Melbourne, Australia

WoodSolutions (2013a) Alternative Solution Fire Compliance: Cross-laminated Timber (CLT). Forest and Wood Products Australia, Melbourne, Australia

WoodSolutions (2013b) Alternative Solution Fire Compliance: Internal Linings. Forest and Wood Products Australia, Melbourne, Australia

WoodSolutions (2013c) Alternative Solution Fire Compliance: Timber Structures. Forest and Wood Products Australia, Melbourne, Australia

WoodSolutions (2013d) Building With Timber - Nine Storeys and Beyond. In WoodSolutions, Design and Build (p. Fact Sheet 1). WoodSolutions

WoodWorks (2010) Fire Safety and Security. Canadian Wood Council, Ottawa, Canada

WoodWorks (2011) Designing for Fire Protection. Wood Products Council, Washington DC, USA

WoodWorks (2012) Wood Buildings Aim High. WoodWorks Case Study WW-002, Washington DC, USA

WoodWorks (2013) The Wood Use Matrix. Retrieved July 29, 2013, from Wood Works!: http://www.woodusematrix.com/resources/wood_matrix_database.php

Wurm J, Gockel T, Unger M (2012) The Life Cycle Tower: A High-Rise in Timber Construction. Arup, London, UK 